\title{
NILAI PENDIDIKAN ISLAM PRESPEKTIF KH. SALAHUDIN WAHID
}

\author{
Dr. Saefrudin, M.Pd.I \\ Dosen FAI Universitas Islam Sultan Agung (UNISSULA) - Semarang
}

\begin{abstract}
Changes in education in modern society in the era of the expectation that is in accordance with the needs of the community, especially to meet the needs in the field of education through the inculcation of Islamic values in the teaching and learning process of students. Islamic education is expected to be an education that is not only as knowledge but Islamic education must be able to be applied to personal learners to the fullest as Muhaimin said that Islamic education that is currently underway in several Islamic educational institutions is more dominant in the transfer of knowledge, while the practical aspects are not serious maximum attention. the transfer of knowledge is very important but far more important is the practice of science itself through Islamic values.Basically, Islamic education is sourced from the Al-Qur'an and Hadith therefore a person who wants to develop the concept of Islamic education must base on the Al-Qur'an and Hadith in an Islamicbased educational institution starting from the stake holders of existing Islamic educational institutions, Therefore, in applying Islamic education there must be Islamic values that must be carried out continuously, so that Islamic education can be applied by stakeholders in Islamic-based institutions, so that these values can become a culture that must be implemented in the environment of Islamic education institutions with such institutions can be good and advanced in the eyes of society or government.Studying KH. Salahudin Wahid Hasyim in the concept of Islamic education, he tried to present the concept of Islamic education through Islamic values that originate from the Qur'an and hadith, such as sincerity, honesty, responsibility, hard work and tolerance (tasamuh). These values must be implemented in the world of Islamic education and Islamic education institutions. Islamic education which is based on the values of the Koran and Hadith provides an opportunity for all students to be directly involved in developing their abilities and talents, so that students are able to become good human beings, have good morals and have active, creative and innovative abilities in accordance with values - the value of good Islamic education.
\end{abstract}

Keywords: Islamic Education Value, KH. Salahudin Wahid 


\begin{abstract}
ABSTRAK
Perubahan pendidikan dalam masyarakat modern di era ekspektasi yang sesuai dengan kebutuhan masyarakat, terutama untuk memenuhi kebutuhan di bidang pendidikan melalui penanaman nilai-nilai Islam dalam proses belajar mengajar siswa. Pendidikan Islam diharapkan menjadi pendidikan yang tidak hanya sebagai pengetahuan tetapi pendidikan Islam harus dapat diterapkan kepada peserta didik secara maksimal karena Muhaimin mengatakan bahwa pendidikan Islam yang saat ini sedang berlangsung di beberapa lembaga pendidikan Islam lebih dominan dalam transfer. pengetahuan, sedangkan aspek praktis perhatian serius tidak serius. transfer pengetahuan sangat penting tetapi jauh lebih penting adalah praktik sains itu sendiri melalui nilai-nilai Islam. Pada dasarnya, pendidikan Islam bersumber dari Al-Qur'an dan Hadits karena itu seseorang yang ingin mengembangkan konsep pendidikan Islam harus mendasarkan tentang Al-Qur'an dan Hadits di lembaga pendidikan berbasis Islam mulai dari pemegang saham lembaga pendidikan Islam yang ada, oleh karena itu, dalam menerapkan pendidikan Islam harus ada nilai-nilai Islam yang harus dilakukan terus menerus, sehingga pendidikan Islam dapat diterapkan oleh para pemangku kepentingan di lembaga berbasis Islam, sehingga nilai-nilai ini bisa menjadi budaya yang harus diimplementasikan di lingkungan lembaga pendidikan Islam dengan lembaga semacam itu bisa baik dan maju di mata masyarakat atau pemerintah. Mempelajari KH. Salahudin Wahid Hasyim dalam konsep pendidikan Islam, ia mencoba menghadirkan konsep pendidikan Islam melalui nilai-nilai Islam yang berasal dari Alquran dan hadis, seperti ketulusan, kejujuran, tanggung jawab, kerja keras dan toleransi (tasamuh). Nilai-nilai ini harus diterapkan di dunia pendidikan Islam dan lembaga pendidikan Islam. Pendidikan Islam yang didasarkan pada nilai-nilai Al-Quran dan Hadits memberikan kesempatan bagi semua siswa untuk terlibat langsung dalam mengembangkan kemampuan dan bakat mereka, sehingga siswa mampu menjadi manusia yang baik, memiliki akhlak yang baik dan aktif, kreatif dan kemampuan inovatif sesuai dengan nilai-nilai pendidikan Islam yang baik.
\end{abstract}

Kata kunci: Nilai Pendidikan Islam, KH. Salahudin Wahid 


\section{A. Pendahuluan}

Di zaman modern ini, era disrupsi, dunia pendidikan mengalami perubahan danperkembangan, hasilnya dari pendidikan tersebut melahirkan generasi-generasi yang diharapkan oleh masyarakat, agama bangsa dan negara. Dalam rangka menghasilkan manusia yang berakhlak mulia dan unggul, seharusnya dalam proses pendidikan senantiasa harus ada evaluasi dan di perbaiki secara terus-menerus sehingga menghasilkan apa yang dicita-citakan oleh lembaga penddikan islam tersebut.

Perubahan pendidikan dalam masyarakat modern, diharapkan sesuai dengan kebutuhan yang ada dimasyarakat, terutama untuk memenuhi kebutuhan dalam bidang pendidikan, melalui penanaman nilai-nilai keislaman dalam proses belajar - mengajar peserta didik. Pendidikan Islam diharapkan bisa menjadi pendidikan yang tidak hanya sebagai pengetahuan saja akan tetapi pendidikan Islam tersebut harus bisa diterapkan pada pribadi peserta didik secara maksimal, sebagaimana Muhaimin mengatakan pendidikan Islam yang sedang berjalan di beberapa lembaga pendidikan Islam lebih dominan transfer ilmu, sementara aspek amaliahnya belum serius diperhatikan secara maksimal, pentransferan ilmu pengetahuan sangat penting akan tetapi jauh lebih penting pengamalan ilmu itu sendiri, melalui nili-nilai keislaman. Pada hakekatnya pendidikan Islam bersumber dari Al-Qur'an dan hadis oleh karena itu seorang yang ingin mengembangkan konsep pendidikan Islam haruslah berpijak pada Al-Qur'an dan hadis di suatu lembaga pedidikan berbasis keislamanan dari mulai staekholders yang ada lembaga pendidikan Islam, Oleh karena itu dalam mengaplikasikan pendidikan Islam harus ada nilai-nilai keislaman yang harus dilakukan secara terus menerus, dengan begitu pendikan Islam akan bisa diterapkan oleh para staekholders yang ada di lembaga yang berbasis keislaman, sehingga nilai-nilai tersebut bisa menjadi budaya yang harus diimplementasikan di lingkungan lembaga pendidkan Islam dengan seperti itu lembaga tersebut bisa baik dan maju di mata masyarakat atau pemerintah.

Mengkaji pemikirin KH. Salahudin Wahid Hasyim dalam konsep pendidikan Islam, beliau berusaha menghadirkan konsep pendidikan Islam melalui nilai-nilai keislaman yang bersumber dari Al-Qur'an dan hadis, seperti nilai ikhlas, jujur, tanggung jawab, kerja keras dan toleransi (tasamuh). Nilai-nilai tersebut harus diimplemntasikan di dunia pendidikan Islam dan lembaga pendidikan Islam. Pendidikan Islam yang yang berdasarkan nilainilai al-Qur'an dan Hadis memberikan kesempatan kepada semua murid untuk terlibat langsung dalam mengembangkan kemampuan dan bakatnya, sehingga murid mampu menjadi manusia yang baik, berakhlak mulia dan mempunyai kemampuan aktif, kreatif dan inovatif sesuai dengan nilai-nilai ajaran pendidikan Islam yang baik. 
Dengan dasar itu, penulis menganggap penting untuk mengkaji lebih dalam lagi mengenai konsep nilai-nilai pendidikan Islam, Dalam pembahasan masalah nilai pendidikan Islam, penulis mengangkat isu-isu konseptual, teoritik dan praktek yang mampu memberikan kerangka pemahaman. Sehingga bisa menunjuk kepada seperangkat tujuan, rencana atau usulan, program-program, keputusankeputusan, serta undang-undang yang dimanfaatkan oleh para elit pengampu kebijakan pendidikan.

Sebenarnya pemikiran K.H. Salahudin Wahid pernah diteliti oleh Erika Nuzul Safitiri dengan judul "Pemikiran Pendidikan Gus Salahudin Wahid" yang isinya tulisan ini menekankan pada perkembangan aspek pendidikan dan sarana prasarana pendidkan. Berbeda dengan penelitian yang tulis oleh Saefrudin, tulisan ini lebih menguraikan bagaimana konsep nilai-nilai pendidikan Islam yang telah diterapkan di lembaga pendidikan islam yaitu di pesantren Tebuireng dan lembaga formalnya pendidakan dasar sampai perguruan tinggi yang telah diterapkan selama 15 tahun, pada lembaga pendidikanya seperti nilai-nilai seperti kejujuran, keikhlasan, kerja keras, tanggung jawab dan tasamuh (toleransi).

$$
\text { Nilai-nilai tersebut diharapkan }
$$
membetuk akhlak peserta didik yang baik, serta terbentuk budaya lingkungan yang sesuai dengan nilai islam, sehingga peserta didik tersebut bisa berguna bagi dirnya, syukur orang lain, lebih jauh agama, bangsa dan negara.

Dengan dasar di atas maka penulis dapat merumuskan pemikiran K.H.Salahudin Wahid menjadi tiga rumusan masalah: Pertama, Bagaimana konsep nilai pemikiran pendidikan Islam menurut K.H. Salahudin Wahid ? Kedua, Bagaimana implementasi nilai pendidikan Islam menurut K.H.Salahudin Wahid? dan Ketiga, Bagaimana evaluasi nilai pendidikan Islam menurut K.H.Salahudin Wahid? Sesungguhnya pendidikan berbasis nilai-nilai keislaman merupakan pendidikan yang harus diimplemtasikan secara terusmenerus sehingga nilai tersebut akan menjadi watak dan budaya dalam berperilaku dan bertindak di lembaga pendidikan Islam. Terlebih tokoh dalam tulisan ini, seorang sosok kyai yang kharismatik dan berpengaruh di kalangan tokoh Agama dan Masyarakat.

\section{B. Nilai Pendidikan Islam menurut KH. Salahudin Wahid}

Nilai Pendidikan Islam dalam Kamus Bahasa Indonesia yaitu, angka, ukuran yang hampir sama dengan prestasi atau sifat yang berguna bagi uamat manusia dalam menjalankan kehidupannya (Kamis, 1997: 376). Milto Roceach dalam Mawardi Lubis “ Nilai ialah sesuatu nilai kepercayaan, mengenai suatu tindakan yang pantas atau tidak pantas yang dilakukan seseorang (Mawardi Lubis, 2011:16). Mengacu pada definisi sesungguhnya nilai adalah suatu hal 
urgen juga berharga untuk manusia sekaligus intisari kehidupan dan diyakini, jikalau manusia tidak mempunyai nilai maka dalam kehidupannya kurang berarti.

Sedangkan Ahmadi berpendapat pendidikan Islam ialah sebagai ikhtiar manusia dalam mengembangkan fitrah potensi anak didik agar mampu, mengetahui memahami dan mengamalkan isi ajaran islam, menuju terbentuknya manusia seutuhnya( insan kamil) ( Ahmad 1992: 20 ). Ada juga yang berpendapat bahwa pendidikan Islam ialah ikhtiar muslim yang bertakwa dengan sadar mengarahkan dan membimbing hidupnya dalam mengembangkan fitrah (kemampuan) khususnya kepada orang muslim dalam mengamalkan ajaran islam(M. Arifin, 2006: 22). Mengacu pengertian diatas dapat kami sederhanakan bahwa nilai pendidikan Islam merupakan kumpulan prinsip hidup yang berisi ajaran islam guna memelihara dan mengembangkan fitrah manusia, menuju terbentuknya manusia seutuhnya (insan kamil) yang selaras dengan aturan atau ajaran Islam. Sesungguhnya nilai pendidikan Islam yang menjadi acuan hidup manusia. Sumber nilai pendidikan Islam berdasarkan nilai falsafah hidup dan nilai agama yang dasarnya AlQur'an dan Al-hadis .

Manusia sebagai hamba Allah telah diposisikan dimuka bumi ini sebagai khalifah sebagai tangan kepanjangan dari Allah swt dalam mengatur dan memakmurkan kehidupan di alam semesta ini. Dengan demikian manusia oleh Allah swt disamping diberikan potensi diri atau fitrah dikemangkan dalam proses pendidikan. Dengan pengembangan diri yang bersifat dinamis itu dia akan mempunyai kemampuan beradaptasi dengan konteks lingkungannya dan memberdayakan sehingga lingkungan dapat memberikan support bagi kehidupanya. Manusia tidak dapat melepaskan diri dari lingkungan merupakan bagian yang menyatu dalam kehidupan manusia itu sendiri. (Djamaluddin, 2010:52)

Pendidikan dalam prespik islam tidak lepas dari peranan manusia dalam mengamban misi sebagai khalifah Allah swt dimuka bumi ini: sesungguhnya Allah (Aku) akan menjadi seorang kholifah dimuka bumi ini (QS. Baqarah, 2:30).

Peran mengemban amanah tidak akan dapat dilaksanakan dengan baik tanpa bekal pendidikan yang optimal. Untuk itu manusia harus mengembangkan potensi dari dalam rangka untuk melaksanakan peran ini agar mendapatkan rahmat kehidupan bagi alam semesta (Djamaluddin, 2010: 3)

Subtansinya pendidikan Islam berpijak pada pendidikan ruhiyah, fikriyah dan amaliyah (aktivitas). Internalisasi keislaman diamalkan dalam pribadi-pribadi manusia kemudian dikembangkan pada ranah pemberdayaan di segala sektor kehidupan manusia (Mudjia Rahardjo, 2010: 31) Zakiah Darajat mengatakan sesungguhnya tujuan pendidikan Islam adalah mencetak manusia yang bermanfaat untuk pribadinya dan 
masyarakat serta gembira dalam mengimplementasikan dan mengajarkan ajaran nilai-nilai pendidikan Islam dalam hal berhubungan Tuhan, manusia dan alam sehingga kita bisa mengambil kemanfaatan dari alam semestasehingga kita bisa mengambil faidah untuk bekal mengarungi kehidupan di dunia dan akhirat. (Darajat, 2008: 30)

Sesungguhnya tujuan pendidikan Islam ialah terbentuknya kepribadian Muslim yang berakhlak mulia, hakekat pendidikan sendiri merupakan usaha sadar untuk mencapai tujuan pribadi yang mempunyai akhlak mulia serta selalu menyerukan kebaikan dan memerangi kemungkaran sebagaimana Dalam alQur'andinyatakan:

Dan hendaklah ada di antara kamu segolongan umat yang menyeru kepada kebajikan, menyuruh kepada yang ma'ruf dan mencegah dari yang munkar. Merekalah orang-orang yang beruntung.

Realita di lapangan, kita bisa lihat amanati secara seksama kenapa masih banyak manusia-manusia yang mempunyai pendidikan yang cukup tinggi akan tetapi moralnya dan tingkahnya lakunya tidak mencerminkan nilainilai dari ajaran pengamalan pendidikan islam. seperti, penyelewangan uang negara (korupsi) yang dilakukan para petinggi negara yang sesungguhnya mempunyai pendidikan yang amat tinggi. Juga tindakan yang melawan hukum masyarakat dan negara misalnya melakukan tindakan meneror, anarkis bahkan sampai terjadi pembunuhan yang korbannya tidak sedikit. Dengan kejadian di atas sesungguhnya pendidikan islam belum berjalan dengan baik bahkan mengalami kegagalan yang signifikan

Ahmad. D. Marimba bahwa pendidikan islam sebagai bimbingan jasmani dan rohani berdasarkan hukum-hukum agama islam menuju kepribadian utama menurut ketentuanketentuan islam Yang dimaksud kepribadian utama adalah kepribadian muslim yang sesuai dengan nilai-nilai keislaman (Marimba D. Mahmud, 2011:24)

Berbeda dengan Omar Muhammad AtToumy Asy-Syaibany mengartikan pendidikan islam sebagai perubahan yang diinginnkan dan diusahakan oleh proses pendidikan, baik tataran tingkah laku individu maupun pada tataran kehidupan sosial serta pada tataran relasi dengan alam sekitar atau pengajaran secara aktifitas asasi, dan sebagai proposi diantara profesi-profesi dalam masyarakat. Intiya pendidikan islam memfokuskan pada perubahan tingkah laku manusia konotasinya pada pendidikan etika (Omar D.Mahmud, 2011:24)

Menurut Tafsir bahwa pendidikan islam adalah bimbingan yang diberikan oleh seorang kepada seorang agar ia dapat berkembang secaram maksimal sesuai dengan ajaran islam, kalau disederhanakan bahwa pendidikan islam adalah bimbingan terhadap seorang agar iya menjadi muslim semaksimal mungkin (Tafsir, 2007:31) 
Selain itu. Ahmad Supriadi berpendapat bahwa pendidikan islam adalah pendidikan yang berdasarkkan ajaran islam atau tuntunan agama islam dalam usaha menimba dan membentuk pribadi muslim dan bertakwa kepada Allah SWT adapun Ahmad Tafsir memaknai pendidikan islam sebagai bimbingan yang diberikan seseorang secara maksimal sesui dengan ajaran islam ( Ahmad, D.Mahmud, 2011:25)

Sesungguhnya pendidikan islam lebih menekankan pada perbaikan sikap mental yang akan terwujud dalam amal perbuatan, baik perbuatan diri sendiri maupun orang lain. Pendidikan islam merupakan pendidkan iman, amal sholeh juga sebagai pendidikan individu dan pendidikan masyarakat. Pada zaman nabi yang mendidik langsung adalah para nabi, rasul, selanjutnya para ulama dan para kyai dan ustadz (Zakiyah Darojat, 2012: 28)

Tujuan pendidikan islam adalah diharapkan setelah seorang mempelajari pendidikan islam dapat terwujudnya kepribadian yang membuatnya menjadi "insan kamil"dengan pola takwa insan kamil artinya manusia utuh rohani dan jasmani dan dapat hidup berkembang secara wajar dan normal karena takwanya kepad Allah SWT. Artinya pendidikan islam diharapkan menghasilkan manusia yang berguna bagi dirinya dan masyarakatnya. Tujuan tersebut terlalau ideal sehingga sering mengalami kegagalan akan tetapi dengan kerja keras dilakukan secara terncana dengan karangka kerja yang konsepsonal mendasar, pasca capaian itu bukanlah sesuatu yang tidak mungkin.

Sedangkan menurut Abdul Fatah tujuan pendidikan islam adalah terwujudnya manusia sebagai hamba Allah swt jalan menyatakan hidupnya manusia seluruhnya menghambakan kepada allah swt islam menghendaki supaya manusia supaya dididik suapaya ia mampu merealisasikan tujuan hidupnya sebagaiman yang telah digariskan Allah swt tujuan manusia menurut Allah ini disinggung pada ayat 56 surat Adzariat:

Dan aku tidak menciptakan jin dan manusia kecuali supaya mereka beribadah kepada ku

Sebagian orang menyangka bahwa ibadah itu hanya sebatas menuikan sholat, puasa ramadhan, menguarkan zakat, ibadah haji dan mengucapkan sahadat. Di luar itu bukan ibadah, ibadah itu mencakup semua amal, ucapan, perbuatan, pikiran dan persaan yang hubungkan dengan Allah swt. Dalam kerangka inilah sesungguhnya tujuan pendidikan islam adalah harus mempersiapkan manusia agar beribadah sebagai hamba Allah swt (Ibad Rahman).

Pembentukan manusia yang bisa mempunyai akhlak yang mulia, kiat untuk memperbaiki akhlak tersebut dengan mengevaluasi kegagalan dalam peroses pembelajaran khususnya dalam pendidikan islam. Model klasik harus di perbaiki dalam hal metode jangan hanya menganggap pesrta didik diibaratkan gentong yang tugasnya hanya selalu menerima air dan menerima air, akan 
tetapi seorang murid seharusnya adanya timbal balik antar murid dan guru atau sebaliknya guru dan murid dalam hal peroses penyerapan ilmu pengetahuan (H.A.R.Tilaar, 2000:145)

Realita di lapangan, bahwasanya pendidikan di Indonesia memang tidak bisa terlepas dari knowledge and power (pengetahuan dan kuasa). Sebagai penentu kebijakan yang diamanati tugas suci adalah pemerintah. Kalau seorang ingin bekerja secara total maka cara tepat ialahharus bergabung pada organisasi pemerintah ketika seseorang masuk dalam maka seseorang bisa menjadi pemutus dan pengendali kebijakan karena dalam hal ini seseorang bisa menjadi pengendali dan penentu kebijakan sehingga memberi kesejahteraan pada masyarakat. Keberhasil seseorang dalam menjalankan amanah adalah maka harus mengacu pada nilai kemanusiaan. Kegagalan dalam melaksanakan amanah menjalankan nilai-nilai kemanusian maka akan berimplikasi sikap anomali(ketidaknormalan), diantaranya: hilangnya rasa kepedulian antara sesama, anarkis, pelajar tawuran dan lain sebagainya. (Sanusi, 2005:1)

Dalam hal yang lain, standar perilaku seseorang yang merupakan cermianan dari nilai kemanusiaan dapat dilihat dari aspek budaya, akal, dan ajaran perihal tersebut memiliki aturan dan formulasi tersendiri serta implikasi terhadap perilaku seseorang.

\section{Biografi KH. Salahudin Wahid}

Mengetahui ketokohan K.H. Salahudin Wahid yang tidak asing lagi di mata masyarakat NU beliau KH. Salahuddin Wahid merupakan tokoh masyarakat (Public figur), beliau cedikiyawan, politik, arsitek dan kyai beliau sebagai tokoh yang disegani dikalangan para kiyai dan militer jawa timur, K.H. Salahudin Wahid kelahiran Jombang, 11 September 1942, K.H. Salahudin Wahid ketiga dari 6 bersaudara pasangan KH. Wahid Hasyim (Ayah) beserta pasangan ibu Nyai Sholichah (Ibu) orang tuanyaK.H. Salahudin Wahidputra dari seorang ulama ketermuka pendiri ormas besar yakni NU beliau rois akbar NU yakni : K.H. Hasyim Asy'ari dan K.H. Bisri Syansurikeduanya pendiri NU sedangkan kakak kandungnya adalah KH. Abdurrahman Wahid (Gus Dur) dari mantan ketua PBNU dan Persiden RI beliau selain seorang ulama, cendikiyawanK.H. Salahudin Wahid juga merupakan seorang, tokoh HAM (Hak Asasi Manusia), politisi, aktifis dan arsitekPengalaman Pendidikan milter jawa timur, beliau kelahiran Jombang, 11 September 1942,.

K.H. Salahuddin pindah ke Tebuireng Pada tahun 1947, menyusul wafatnya K.H. Hasyim Asy'ari yang digantikan oleh ayahnya, KH. Wahid Hasyim. Selanjutnya pada awal tahun 1950, ketika ayahnya diangkat menjadi Menteri Agama, KH. Salahuddin ikut pindah ke Jakarta.Pendidikan dasarnya ditempuh di SD KRIS (Kebaktian Rakyat Indonesia 
Sulawesi), dimana para gurunya banyak yang menjadi anggota pergerakan nasional, termasuk orang-orang PKI. Semasa di sekolah ini membuatnya terbiasa hidup di lingkungan yang majemuksehingga sudah terbiasa menghadapi perbedaan. Ketika naik ke kelas IV, Salahuddin pindah ke SD Perwari yang terletak di seberang kampus UI Salemba. Pada1955-1958, KH. Salahuddin melanjutkan sekolahnya di SMP Negeri I Cikini. Di SMP ini ia memilih jurusan B (ilmu pasti). Setelah lulus SMP ia masuk SMA Negeri I yang populer dengan sebutan SMA Budut (Budi Utomo), karena terlatak di Jalan Budi Utomo. Selama di SMA Budut, K.H. Salahuddin aktif di Kepanduan Ansor dan OSIS.Tahun $1962 \quad$ K.H. Salahuddin selesaidariSMA beliau melanjutkan pendidikannya ke Institut Teknologi Bandung (ITB), sejak kecil K.H. Salahuddin bersama saudara-saudaranya juga belajar mengaji. Ini merupakan aktivitas rutin yang wajib dilakukan setiap hari. Ketika ayahnya masih hidup, kegiatan mengaji dipimpin langsung oleh sang ayah. Setelah K.H. Wahid wafat, tugas itu diambil alih oleh sang ibu. KH. Bisri Syansuri yang sering ke Jakarta, juga ikut mendidik mereka. Selain belajar membaca Al-Qur'an, remaja Salahuddin juga belajar fiqh, nahwu, sorof, dan tarikh. Guru-gurunya antara lain Ust. Muhammad Fauzi dan Ust. Abdul Ghoffar. Keduanya alumni Pesantren Tebuireng yang tinggal di Jakarta. K.H. Salahuddin sempat merasakan pendidikan pesantren melalui Pesantren Ramadhan. Setiap ada waktu longgar, K.H. Salahudin Wahid selalu menyempatkan diri membaca. Kebiasaan ini semakin intens di bulan Ramadhan. Dalam satu bulan, sepuluh judul buku bisa habis dibacanya. Menurut pengakuan, K.H. Salahudin Wahid dia biasanya menyediakan waktu untuk membaca sebelum dan sesudah makan sahur, setelah Salat Shubuh, pagi hari, dan setelah sholat Ashar.

\section{Penggerak Moral}

Di tengah-tengah kesibukannya mengurus Tebuireng, K.H. Salahudin Wahid tetap aktif menjalankan berbagai kegitan diluar pondok. Beliau aktif mengisi seminar, lokakarya, saresehan, workshop, bedah buku, juga melayani wawancara dan telewancara dengan berbagai media cetak maupun elektronik.

K.H. Salahudin Wahid aktif juga dalam kegiatan-kegiatan soosial termasuk membantu kebakaran Pasar Surabaya, tanah Abang Jakarta, korban luapan lumpur Lapindo Sidoarjo. Beliau juga tercatat sebagai anggota forum Pemantauan Pemberantasan Korupsi (2004), Barisan rakyat sejahtera (Barasetra), Forum Indonesia bersatu (FIS), Kajian Masalah Kepahlawanan yang dibentuk oleh Ikatan Keluraga Pahlawan Nasional Indnesia(IKPNI), menjadi ketua Gerakan Integritas Nasioanal, dan lain-lain. Beliau diminta menjadi Penasehat Federasi organisasi Perdagangan Pasar Indonesia di Jakarta, yang memperjuangakan nasib para pedagang 
tradisional yang tergusur dan pasar-pasar yang diubah menjadi mall.

K.H. Salahuin aktif dalam mendampingi korban Lapindo. Beberapa kali beliau hadir di Porong, mendampingi korban menemi Bupati Sidoarjo, membuka pameran foto karya anak-anak korban Lapindo, menerbitkan buku dan mendirikan Gerakan Memantau lumpur Lapindo. Juga menulis artikel membela korban Lapindo. Koran kompas pernah menerbitkan karikatur tokoh pembela pembela Lapindo yaitu: K.H..Salahudin, Buya Syafii Maarif, Romo Fransz danRomo Magnis Suseno. K.H. Salahudin Wahid tidak akan pernah berhenti memperjuangkan nilai-nilai moral. Bukan hanya sebagai salah tokoh nasional yang di guru dan ditiru tapi juga sebagai muslim menyempurnakan akhlaqul karimah adalah misi utama setiap umat Nabi Muhammad saw yang ingin meneladani, bukti ektitensi dan konsistensi K.H. Salahudin Wahid dalam menyuarakan pentingnya nilai-nilai moral bersama dengan tokoh nasional yang diberinama Gerakan Integritas Nasional (GIN) (Taufiqurahman, 2011:91)

\section{Sosok Penyatuan}

Di antara putara-putra K.H. Wahid Hasyim, K.H. Salahudin dikenal masyarakat sebagai sosok yang amat penyantun dan mirip dengan bapaknya. Tutur katanya halus dan pembawaanya tenang. Orang yang sekali berjumpa dan belum banyak berbicara dengannya, mungkin akan menduga bahwa laki-laki kelahiran jombang, agak tertutup padahal beliau amat terbuka dan menerima siapapun yang ingin bertemu dengannya. Bahkan, melalui akun twiter-nya, K.H.Salahudin Wahid selalu menjawab siapa saja, yang menyapanya dan menanggapi berbagai persoalaan atau pertanyaan yang diajukan kepadanya. Karena itu, tidak heran kalau setiap hari, rumahnya didatangi oleh banyak orang muda dari berbagai kalangan untuk berdialog.

K.H. Salahudin Wahid dianggap kurang tegas karena tidak mau memihak ketika ada dua kelompok bertikai. Padahal sebenarya, sikap K.H.Salahudin Wahid itu tegas dengan argumentasi yang jelas. Beliau tidak mau memihak karena yang dibelanya adalah prinsip bukan kelompok. Kalau K.H.Salahudin Wahid memihik kelompok, beliau khawatir akan bergeser dari prinsip yang dibelanya.Tetapi pembelaan prinsip itu ada kalanya harus menyesuikan diri dengan realitas yang dihadapi.(Taufiqurahman, 2011:91)

Dalam memandang persoalan, terlihat sekali bahwa K.H. Salahudin Wahid berusaha jernih, tidak hitam putih. Beliau memandang dari berbagai sudut pandang dan menilai secara seimbang.Untuk itu, beliau kumpulkan dulu inforasi-informasi yang ada, lalu dikelompokannya, kemudian barulah beliau rangkai menjadi sebuah susunan yang seimbang. 
Beliau terlihat tidak mengejar jabatan, tetapi kalau ditawari dan merasa sanggup untuk menjalaninya, beliau tidak akan menolak.Kalau diberi tugas, K.H.Salahudin Wahid akan kerja sebisa mungkin. Adik K.H.Abdurahman Wahid itu adalah sosok yang rendah hati dan tidak ingin menonjolkan diri. Beliau tidak oportunis, walaupun bagi sebagaian orang dianggap kurang tegas.KH.Salahudin Wahid tidak alergi terhadap kritik, bahkan senang dengan anak muda yang mengiritiknya termasuk dari anaknya sendiri

Menurut Mukhsin Kasmin dalam bukunya imron arifin kepemimpinan kyai dalam perubahan Manjemen Pondok Pesantren Tebuireng ada 8 kelebihan yang dimiliki K.H.Salahudin Wahid diantaraya: pertama pendidikannya tinggi bergelar insiyur, kedua, berpengalaman luas dibidang kenegaraan, sosial, budaya, kemanusiaan dan pendidikan, ketiga, memiliki relasi luas, ke empat, melakukan kajian ilmiah dalam mengembangkan semua unit pesantren, ke lima, mendatangkan guru, para pakar dan kyai yang kompeten dan profesioanal, ke enam berani dan cepat mengambil kebijakan dalam meningkatkan mutu, ke tujuh, secara ekonomi K.H.Salahudin Wahid cukup kuat sehingga tidak mencari hidup di pesantren, justru menghidupi pesantren kedelapan,Putraputranya telah menjadi orang atau sukses sehingga tidak ngeribeti, malahan meberi bantuan terhadap proyek-proyek pesantren. Tentaunya kalau digali lebih banyak lagi keunggulan yang ada dalam sosok K.H.Salahudin Wahid.Taufiqurahman, 2011:95)

\section{Menyatukan Hati Bani Hasyim}

Hal terpenting dan paling awal yang ditempuh K.H. Salahudin Wahid alam rangka revitalisasi Tebuireng ialah menggandeng keluarga besar Bani Hasyim Asy'ari untuk ikut serta membangun Tebuireng. Mereka dimintai saran, masukan, dan peran aktif dalam mengemban amanah meneruskan perjuanganHadratus syekhKH Hasyim Asy'ari.

Kesatuan hati dan tekad dari semua keluarga besar kiai Hasyim Asy'ari merupakan kekuatan moral paling dahsyat bagi K.H.Salahudin Wahiddalam memimpin pesantren Tebuireng. Mengingat, potensi dan skill yang dimiliki dzurriyyah kiai Hasyim Asy'ari yang tersebar di mana-mana adalah cukup besar dan kuat untuk menopang kekuatan Tebuireng. Tidak mudah memang, sebab masing-masing orang memiliki idealism sendiri-sendiri. Namun, atasnama pengembangan pesantren Tebuireng yang sejatinya adalah merupakan amanah bagi semua Bani Hasyim Asy'ari, akhirnya K.H.Salahudin Wahid pun mampu menyatukan hati dan pikiran mereka semua (Taufiqurahman, 2011:54)

\section{Lokomotif Pendidikan}

Dalam bidang pendidikan, K.H. Salahudin Wahid melakukan perombakan 
kurikulum sekolah, yang dianggapnya kurang bermanfaat dihilangkan. Proses pendidikan dimana pun, tak terkecuali di pesantren, tidak bisa lepas dari kualitas guru sebagai sumber ilmu, sebagai fasilitator, teladan, mitra diskusi dan teladan bagi para santri dan siswa-siswi Tebuireng.

Untuk itulah, dalam upaya meningkatkan kualitas para guru dalam proses belajar mengajar, mereka diberi penataran tentang metode mengajar yang baik, diberi kesempatan atau beasiswa untuk meneruskan jenjang pendidikanya, disediakan fasiltas yang cukup serta kesejahteraan yang memadai. Di atas para guru, ada kepala sekolah. Dialah yang bertanggung jawab terhadap keberhasilan pendidikan di lembaganya sehingga posisi kepala sekolah harus diisi oleh orang-orang yang benar-benar mampu di bidangnya supaya pendidikan tidak hanya asal-asal. Asal jalan, asal belajar, asal ada, dan seterusnya.

Dalam sebuah kesempatan, K.H. Salahudin Wahid menegaskan, "Untuk meningkatkan mutu pendidikan, kuncinya ada di posisi kepala sekolah atau madrasah. Karena, pemimpin adalah lokomotif yang menarik semua gerbong. Agar obyektif, saya bekerja sama dengan pihak KPI (Konsorsium Pendidikan Islam, kini menjadi Kualita Pendidikan Indonesia) untuk melakukan uji kompetensi kekepala sekolahan, yang diikuti oleh kepala sekolah dan guru yang berminat menjadi kepala sekolah. Selanjutnya, diadakan penjaringan sehingga yang menjadi terpilih kepala sekolah atau madrasah adalah orang yang benar-benar memenuhi kualifikasi. Pendekatan ini tidak menyinggung atau membuat sakit hati kepala sekolah yang ada, sebab diadakan secara objektif, transparan, berorientasi kepada mutu, dan dilakukan oleh pihak rekanan yang tidak memilii kepentingan politis di pesantren".Gebrakan suksesi serentak dilingkungan pendidikan pesantren Tebuireng itu merupakan perubahan revolusioner yang dilakukan K.H. Salahudin Wahidsebagai pengasuh pesantren. Para guru, santri dan alumni, termasuk juga keluarga besar Bani Hasyim, menyambut baik revolusi pendidikan ala K.H Shalahudin Wahid. Meraka mengaku senang dengan perubahan spektakuler demi tujuan mulia itu. Meski kemudian ada suksesi jabatan kepala sekolah,namun hal itu dianggap sebagai hal biasa demi peningkatan mutu pendidikan di Tebuireng. Tidak ada gejolak, semua berjalan dengan baik, dan para kepala sekolah yang tidak lagi (Salahudin, 2011:56)

$$
\text { Dalam buku yang berjudul““ }
$$

\section{Kepemimpinan}

Kyai”K.H.Salahudinmerupakan

seorangPendidik",Imron

arifin

menerangkan,performance

K.H.Salahudin

Wahidmenjelaskan bahwa beliauadalah seorang pendidik yang mencitai kemanusiaan.Denganmeggunakanpendekatank ebebasan bagi yang dididik tidak lagi ditempatkan sebagai objek, tetapi subjek, guru dan murid juga sama-sama belajar. K.H.Salahudin Wahidmenyampaikan 
bagaimana pentingnya mengamalkan dan menanamkan sikap percaya diri, dan tidak bergantung pada orang (mandiri).Di sisi lain, K.H. Salahudin Wahidmenyampaikan pentingnya menanamkan dan mengamalkan perilaku percaya diri kata beliau :"kami kemukakan sedikit pengetahuan dan pengalaman kami tentang pendidikan yang menuju kepada kepercayaan kepada tenaga dan kekuatan diri sendiri”. Di buku tulisan yang lain K.H. Salahudin Wahid menekankan betapa pentingnya menanamkan sikap percaya diri dan selalu mandiri dengan metode mengungkapkan pengembangan pendidikankeluarga. Dalam buku A. Athiatullah yang berjudul London, menjelaskan teradisi di negara Inggris orangorangnya ketika menginjak sudah dewasa, dia beri kamar sendiri kemudian dibawakan perabotan dikamarnya, diantaranya, ranjang, meja, rak, kursi, lampu dan lain sebagainya. Kemudian anak anak tersebut diberikan bekal jajan satu minggu sekali bukan tiap hari (Abuddinata, 2005:34)

Pada 2006 generasi ketiga mengambil alih kepemimpinan pesantren Tebuireng. Saya selaku pengasuh menyadari bahwa siapapun yang menjadi pengasuh Tebuireng, tidak mungkin menggantikan posisi hadrosyekh, dari segi keilmuan maupun ketokohan. Karena itu pesantren Tebuireng harus mengandalakan pada organisasi dan jaringan,Dr Sudjatmoko, pernah mengatakan bahwa pesantren berpotensi menjadi lembaga pendidikan terbaik kalau dikelola dengan manajemen modern. Kepemimpinan Pengasuh menjadi syarat utama dalam mengembangkan Pesantren Tebuireng Menghidupkan kembali madrasah Mualimin sebagai upaya untuk menghidupkan kembali teradisi pesantren salaf. Kelas Musyawarah digatikan oleh Ma'had Aliy yang diakui oleh kementrian Agama.

Pada 2013 IKAHA meningkat dan kembali menjadi Universitas Hasyim Asy'ari dengan lima di luar fakultas Agama Islam yaitu: FakultasTeknik, Fakultas Informatika, Fakultas pendidikan, Fakultas sastra dan Fakultas Ekonomi Syariah dengan jumlah mahasiswanya 1200 meningkat sekitar 3400, pada tahun ini. Untuk menggantikan kelas musyawarah, pada tahun 2006 didiriakn Ma'had Aliy dengan jumlah mahasiswa sekitar 250 .

Mulai 2013 Pesantren membuka banyak sekolah dan madrasah baru yang dibangun dibergai milik Pesantren Tebuireng yang terletak diberbagai kecamatan di kabupaten jombang.jumlah santri meningkat dari 12.00 pada 2007, menjadi sekitar 45.00 pada 2019. Kami merencanakan untuk membangun madrasah dan pesantren baru dikecamatan kesamben Jombang dan memperoyeksikan sepuluh tahun lagi sejumlah santri meningkat menjadi 6.000.Kami telah membuka sekitar sepulu cabang di luar jawa dan merencanakan untuk membangun dua sampai di luar jawa. Penemuan teknologi komunikasi menimbulkan perubahan mendasar dalam kehidupan 
termasuk pendidikan. Pesantren harus siap menghadapi tantangan ini. Internet akan memberi banyak informasi kepada siswa, sehingga mereka harus diberi tahu cara menyaring dan menganalisisnya. Banyak pengamat pendidikan yang memperkirakan bahwa jumlah sekolah dan jumlah Uniersitas di Amerika Serikat akan berkurang separoh pada tahun 2030, Gejala ini akan melada indonesia juga kecenderungan ini harus dihadapi dan diantisipasi. Pesantren mempunyai banyak keuntungan sehingga mungkin bisa bertahan kalau mampu melakukan sejumlah perbaikan. (Salahudin Wahid, 2019: 7)

\section{Penekanan nilai-nilai Akhlak dalam mengambil Keputusan}

Mengambil keputusan rapat yang disetujui dan disepakati oleh semua peserta dan pemangku kepentingan merupakan kelebihan yang ada di Tebuireng, keputusan diputuskan secara bersama-sama dan laksanakan secara bersamasama. Penekanan pada nilai-nilai akhlak dalam mengambil keputusan selalu dilaksanakan baik secara kecil(musyawarah antara santri, antar pengurus kamar dan pembina pondok) atau sekala menengah antar unit-unit sekolah /madrasah dengan penjamin mutu) sekala agak besar (antara bidang-bidang yang satu dengan biang yang lain, unit-unit pendidikan dan antar bidang) maupun sekala besar yang melibatkan dzuriyah pesantren Tebuireng.

Kampaye yang sering didengungkan oleh K.H.Salahudin Wahid adalah perilaku jujur beliau menegaskan bahwa inti dari akhlak itu kejujuran. Terdapat nilai-nilai dasar yang dikembangkan, pertama sikap jujur dalam mengerjakan pekerjaan misal semua guru dan karyawan datang tepat waktu, guru harus memberi uswah, guru mengajarkan siswa harus berpelilaku jujur pembina di pesantren harus mengajarkan kejujuran, kedua sikap jujur dalam meraih nilai disekolah, bekerja keras dalam belajar dan memperoleh nilai di kelas ke tiga sikap jujur dalam meraih prestasi diniyah misalnya santri harus bekerja keras dalam belajar dan memahami materi-materi diniyah.

\section{Implementasi Pendidikan Islam Prespektif Pemikiran KH. Salahudin Wahid di Lembaga Pendidikan Islam}

Dengan semangat memajukan pesantren Salahudin Wahid menjadi pemimpin pesatren Tebuireng sebagai pengasuh pesantren, menggatikan pak K.H. Yusuf Hasyim juga sebagai paman beliau, pak K.H. Yusuf Hasiyim menelepon dan menyampaikan niatnya untuk mundur dari jabatan pengasuh Tebuireng. Pak K.H.Yusuf Hasyim supaya menerusan kepemimpinannya sebagai pengasuh pesantren Tebuireng, meminta K.H. Saahudin Wahid untuk menggantikannya pada bulan Februari 2007

Sesuai namanya K.H. Salahudin yang berarti "reformasi" pada era penyatuan Islam dan kejayaan Islam bisa mengalahkan peperangan dengan nasrani yakni perang salib 
maka beliau merupakan tokoh era pembahuran Islam masa modrn, maka selaku pengasuh pesantren Tebuireng, K.H. Salahudin Wahid atau sang reformasi pendidikan pesantren Tebuireng ini layaknya panglima perang Salahudin Al-Ayubi memerangi musuh-musuh pendidikan atau dalam bahasa K.H.Salahudin Wahid "penyakit"di tubuh Tebuireng harus segera ditemukan, diobati dan disembuhkan sebelum menjadi penyakit kronis yang membahayakan.

Dalam melaksanakan program diagnosanya,sejakbulan April hingga akhir 2007 K.H. Salahudin Wahid mengadakan rapat secara bersama unit-unit yang dibawah naunganYayasan Hasyim Asy'ari beliau meminta laporantentang kendala yang dihadapi, disamping minta masukan maupun kritikan dari mereka. Bahkan, K.H. Salahudin Wahid menurunkan "mata-mata"yang terjun langsung ke kamar-kamar untuk menanyai para santri tentang kinerja pengurus dan apa sajakinerja yang kurang dari pesantren Tebuireng dan apapula harapan mereka dari pesantren tempat menima ilmu (Taufiqurahman, 2010: 23)

Gaya kepemimpinan K.H. Salahudin Wahid mengingatkan kita terhadap kholifah umar bin khattab yang kerap kali turun ke langsung lapangan dan ke daerah-daerah untuk mengetahui nasib rakyatnya sehingga ditemukan aspek-aspek kekurangan yang penuh dibenahi. Begitu besarnya tegad K.H. Salahudin Wahid, ini tidak berlebihan jika masa kepemimpinan Kyai Salahudin Wahid disebut-sebut juga sebagai“Era Revitalisasi” Semasa K.H. Salahudin Wahid Pesantren Tebuireng melakukan beberapa revilitalisasi, melalui peningkatan pendidikan peremajaan sarana fisik, sehingga pembenahan struktur dan manajemen organisasi. Manajerial K.H. Salahudin Wahid secara manajerial telah melibatkan semua elemen untuk sama-sama melaksanakan pembahuran pesantren, dengan melibatkan elemen yang ada (involment) semua elemen dan kepemimpinan yang terbuka (open demokratis) telah menghasilkan dukungan yangkuat dari keluarga pesantren karena mereka ikut merasa terlibat dan bertanggung jawab, dengan keterlibatan itu maka lahirlah iklim demikratis, teransparan dan upaya bersama dalam perbaikan kualitas sehingga pada akhirnya K.H.Salahudin Wahid secara efektif berhasil mempengaruhi warga pesantren dan masyarakat luas untuk mencapai tujuan pesantren dalam konteks pembaharuan dalam hal pembaharuan pendidikan (Taufiqurahman, 2010: 23)

Beliau adalah seorang yang rasionalismanajerial. Kharisma K.H.Salahudin Wahid dilatari oleh anggapan komunitas pesantren bahwa pemimpin pesantren dewasa ini memiliki kualitas-kualitas keunggulan yang dapat membawa jalan keluar atau perbaikan bagi institusi pesantren.

Seiring dengan perkembangan zaman saat ini, yang lebih banyak muncul justru pemimpin-pemimpin kharismatik yang tidak 
dilatari kekuatan agama, tetapi didasarkan pada kualitas komitmen yang tinggi dari pemimpin yang senantiasa bersedia berkorban bagi pencapaian tujuan organisasi, pemimpin yang mampu memberikan harapan masa depan yang lebih baik atau memecahkan masalah yang sedang dihadapi (Taufiqurahman, 2010: 56)

Pada awalnya, K.H.Salahudin Wahid bukanlah original pemimpin pendidikan, sebab beliau tidak memiliki latar belakang dan kualifikasi pendidikan. K.H Salahudin Wahidadalah seorang arsitek yang lama bergelut dalam bindang manajemen. Tak salah, jika pada awal kepemimpinananya, untuk menghadapi lemahnya manajemen pendidikan dan pembelajaran di lingkungan pesantren, K.H Salahudin Wahidmenggunakan tenaga konsultan pendidikan untuk melakukan pembinaan dan perbaikan. Dengan kata lain, kelemahanya dibidang pembelajaran dapat diatasi dengan menggunakan jasa agen eksternal yang representati. Gagasan yang pernah disampaikan Kiai Yususf Hasyim bahwa ke depan pesantren tidak harus dipimpin seorang kiai yang ahli dibidang agama, tetapi dibutuhkan seorang pemimpin manajerial, sebagaimana rumah sakit yang baik tidak harus dipimpin dokter, tetapi dapat dipimpin manajer, tampaknya tidak hanya diwakili Kiai Yusuf Hasyim, tetapi juga oleh penerusnya, Kiai Salahuddin Wahid. Kepemimpinan

Salahudin Wahid yang berpola rasionalmanajerial merupakan kepemimpinan yang mengintegraskan kepemimpinan yang semua stakhakdes dilibatkan seperti guru, karyawan, terutama keluarga semua harus terlibat sesuai dengan kapasitas kemampuanya dalam memajukan pesantrean tebuireng, bagi K.H. Salahudin Wahid, melakukan sebuah perubahan harus dimulai sikap disiplin dan ini tidak boleh ditawar-tawar lagi, Semua orang yang ada di Tebuireng, harus disiplin dalam segala hal, ingin mencapai cita-cita besar dimasa depan. Disiplin adalah bagian dari reformasi pendidikan dan kelembagaan yang digerakan K.H. Salahudin Wahid di Tebuireng. Dengan kata lain penyakit kronisdilingkungan pesantren khususnya di tebuireng setelah diagnosis hasilnya lemahnya kedisplinan, mengingat selama ini di dunia pesantren selalu identik denagan kelambanan seadanya Untuk meningkatkan kedisiplinan dikalangan santri sampai-sampi gus sholah dilibatkan Kepolisian Resort Jombang dan Kuwatir Cabang Gerakan Pramuka Jombang sebagai narasumber untuk memberi pencerahan kepada semua santri. (Taufiqurahman, 2010: 23)

Selain disiplin terhadap peraturan, hal yang tidak kalah pentingnya lagi adalah disiplin santri dalam menjaga kebersihan, bukan hanya di Tebuireng, pola hidup yang tidak besih dan cuek dengan keasrian serta keindahan lingkungan sekitar pesantren, seakan telah menjadi budaya santri. Parahya lagi, penyakit kulit dianggap biasa dan dinilai sebagai 'cap santri” terutama santri baru. Pola pikir keliru dan lemahnya mental mentalitas budaya bersih tersebut menjadi pekerjaana besar K.H. 
Salahudin Wahid diawal kepemimpinanya tidak salah beliau mengatakan, terdapat beberapa tantangan yang harus dihadapi oleh pesantren secara umum, setidaknya, dalam pengamatan saya: Pertama persoalan mutu pondok pesantren. Pada saat ini, di indonesia terdapat jenis pesantren pesantren salaf seperti: pesantren salaf murni seperti Sidogiri, Lirboyo dan Langitan. Sedeangkan pesantren khalaf sepert: Gontor Darunnajah dan, lain-lain adapun tantangan yang di hadapi pesantren secara umum:

Pertama, Di pesantren belum ada pemetaan dari mutu pesantren yang telah ada. Tetapi mutunya tidak sebaik mutu pesantren tersebut hampirlalu. Untuk mutu ilmu agama, diperlukan setandar mutu yang bisa menjadi acuan bersama. Untuk jenis (c) pesantren yang harus mempunyai madrasah/sekolahyang menggunakan kurikulum pemerintah, dimasa depan setanda ilmu non agama harus mengambil acuan setandar internasioanal, karena dalam dunia menggelobal, di indonesia pun kita harus bersaing dengan tamatan sekolah internasional, Kedua, peroblem pendidikan akhlak dari lulusan lembaga penddikan di indonesia termasuk pesantren jumlah umat Islam yang taat menjalani ibadah mahdahah bertambah yang dulu abangan Islam KTP kami sudah menjalani ibadah mahdoh. Tetapi, perilaku umat-umat Islam tidak semakin baik (Salahudin, 2011:25)

K.H. Salahudin Wahid dalam meningkatkan kualitas sumber daya manusia diawali melalui bidang pendidikan khususnya dalam membenahi, mengembangkan dan memajukan pesantren. Kita dapat simpulkan, bahwa kualitas manusia muslim sangat ditentukan oleh tinggi rendahnya kualitas ruhani dan jasmani serta akal.

Jasmani bisa dikatakan sehat ketika tidak ada gangguan fisik ketka melakukan aktifitas. Berbeda dengan kesehatan ruhani indikatornya peningkatan ketakwaan iman kepada Allah SWT kemuadian diimplenasikan dalam kehidupan bermasyarakat sedangkan nalar (akal) fungsinya memberikan dan menunjukan solusi yang adil dan benar sesuai dengan ajaran-ajaran yang dibawa Nabi Muhammad yaiu ajaran islam (Dhofier, 2010:76)

Salahudin Wahid, berpendapat bahwasanya dengan sikap terbuka, sangat diperluakan dan menjadi prinsip dalam menjalin hubungan dimasyarakat, agama menyuruh saling tolong menolong dan bekerja sama pada aspek-aspes sosial, asal tidak menyangkut masalah-masalah akidah dan urusan agama contohnya pada zaman dulu Khalifah Harun al-Rasyid beliu seorang muslim yang taat menjalankan ibadah, akan tetapi dalam tenaga ahli penggunaan tenaga ahli, para Khalifah tersebut merasa tak terhalangi untuk menggunakan tak terhalangi menggunakan tenaga non muslim misalnya kepala perpustakaan mengetahui, juga dokter kesehatannya orang non muslim. Oleh karena itu kedudukan yang penting diserahkan dan 
diamanhkan orang non muslim" oleh karena nilai pendidikan Islam mengembangkan sikap terbuka dan toleran (tasamuh). Intinya muslim senantiasa harus menjadi umat yang selalu menghormati dan menghargai perbedaan, bahkan kerjasama hubungan sosial diperbolehkan sampai yang penting jangan mengganggu nila - nilai keberagaman agama dan aqidah (Rifai, 2009:21)

Menurut K.H.Salahudin Wahid akhlak intinyaadalah kejujuran. Faktanya kita kurang berhasil dalam menemukan kejujuran ke dalam diri murid. Survy Kompas pada pertengahan 2017, bahwa tingkat kebohongan dikalangn pelajar atau mahasiswa tidak menggembirakan, yang selalu jujur hanya, 2,3 persen yang sering jujur 7,5 persen, yang kadang-kadang jujur 50,5 persen; yang sering berbohong 30,8 persen, dan yang selalu berbohong 5,8 persen, Yang selalu bohong adalah 2,5 kali yang selalu jujur. Sebenarnya guru pertama dan yang paling utama bagi anak-anak adalah orang tua, sedangkan sekolah melengkapi dan berusaha memperkuat. Sayang sekali masa sekarang dikota-kota besar banyak suami dan istri harus bekerja dalam memenuhi segala kebutuhan keluarga. Mereka berangkat pagi-pagi sekali dan sering pulang saat mendekati malam. Jumlah mutu pertemuan anak dengan orang tua menjadi kurang, anak-anak banyak yang dititipkan pada pembantu atau saudara. (Salahudin Wahid :2019:1). Di pesantren, yang umumnya menerima santri tamat SD, tanggung jawab membentuk akhlak santri beralih dari orang tua kepada pesantren guru atau ustadz. Di pesantren murid atau santri tidak akan mengalami tawuran, amat kecil kemungkinan menjadi pecandu narkoba. Di banyak pesantren diterapkan dengan ketat larangan merokok. Di semua pesantren ditanamkan semua kejujuran dengan berbagai cara. Hasil survai di atas tentang kejujuran pemuda atau mahasiswa perlu menjadi bahan renungan sejauh mana kejujuran berhasil kedalam diri santri, di dalam lingkungan pekerjaan, terutama di lembaga lingkungan pemerintah, para pemuda secara perlahan mungkin akan menghadapi situasi yang bisa mengkikis kejujuran yang sudah tertanam. Kalau menjadi pengusaha rekan pemerintah, mereka harus mensesuaikan diri dengan peraktik usaha yang sering dihadapkan peraktik wilayah abu-abu. (Salahudin Wahid : 2019:5)

Perlu diketengahkan hasil survai oleh Raiz Hasan dari firlendis Universiyt Australia Hasilnya amat positif $96 \%$ umat Islam Indonesia menjalankan kewajiban sholat, di Mesir berjumlah $87 \%$ di Pakistan mencapai 58\% dan di kazaktan hanya 49\% 99\% muslim di indonesia di Mesir berpuasa, di Pakistan mencapai 93\% dan di Kazaktan hanya 19\%. Tetapi hasil amat positif didalam ketaatan menjalankan ibadah mahdahah itu amat kontras dengan fakta dilapangan yang tidak menunjukan dampak positif dari ketaatan muslimin indonesia. menjalani ibadah mahdhah terhadap perilaku sosial di dalam kehidupan sehari-hari. Kita tahu bahwa korupsi 
di indonesia luar biasa parahnya. Permainan uang terjadi dalam pemilu dan dalam pemilihan ketua dari partai politik termasuk dan berbasis masa Islam. Bahkan dalam pemilihan ketua ormas Islam tertentu permainan uang yang sering terjadi sekitar $60 \%$ pelajar dan mahasiswa /i di kota besar pernah melakukan hubungan seks pra nikah. Kemiskinan terjadi dibanyak tempat dan tidak banyak dari kita yang bergerak membantu mereka. Kontras dengan itu banyak dari kita hidup mewah. Itu semua menunjukan bahwa ibadah mahdhah tidak sejalan/sejiwa dengan dengan ibadah sosial adalah tanggung jawab kita bersama khususnya lembaga pendidikan Islam untuk membangun apa yang oleh Bung Karno dikatakan sebagai national and character bulding yang saat ini melemah. Mungkin pendidikan agama indonesia termasuk dibanyak pesantren ini baru sebatas pengajaran yaitu transfer ilmu pengetahuan keagamaan yang bersifat kognitif. Pedidikan yang bersifat efektif dan psikomotorik belum banyak tersentuh. (Salahudin Wahid, 2011:25)

Internalisasi nilai-nilai agama (yang sebenarnya bersifat universal), ternyata belum berjalan dengan baik. Sejauh pengamatan, bukan berjalan bukan bersadar penelitian, akhlak tamatan pesantren dan sekolah-seklah Islam masih lebih baik dibandingkan tamatan sekolah dibanyak tempat. Pembentukan karakter atau pendidikan akhlak umumnya juga baru sebatas menghafal dan / memperkenalkan nilai tetapi belum sampai pada penghayatan nilai-nilai itu apalagi sampai menjadikan nialinilai itu sebagai komitmen pribadi di dalam kehidupan.

Tentu cukup banyak lulusan pesantren yang berakhlak baik, tapi banyak juga yang tidak baik. Kita perlu menyiapkan tamatan pesantren dan madrasah supaya menjadi muslim yang percaya diri, tanggung jawab, punya motivasi kuat, siap bekerja keras, ikhlas jujur, sederhana, rendah hati (bukan rendah diri), bahwa wawasan luas, saling percaya dan mampu bekerja sama. Akan lebih ideal apabila mereka dipersiapakan menjadi pemimpin yang efektif, karena banyak dari mereka kenyang kemudian menjadi pemimpin informal.

Menurut Erie Sadewo dalam bukunya "Best Prac tice Character Bulding" definisi akhlak atau karakter adalah kumpulan sifat baik yang menjadi tingkah keseharian, sebagai perwujudan kesadaran menjalankan tugas, fungsi dan tugasnya dalam menjalankan amanah dan tanggung jawab. Menurutnya karakter dibagi dua katagori: pokok dan karakter pikiran. Karakter pokok dibedakan menjadi tiga bagian penting adalah karakter unggul, karakter dasar, dan karakter pemimpin. Karakter dasar menjadi karakter intidari karakter pokok, yang ditopang tiga nilaiyang menjadi sifat dasar manusia yaitu tidak egois, jujur dan disiplin karakter pokok kedua ialah karakter unggul yang dibentuk tujuh sifat baik yaitu ikhlas, sabar, bersyukur, tanggung jawab, berkorban, perbaiki diri, sungguh-sungguh, karakter pemimpin memiliki 
sembilan nilai pembentuk yaitu: adil, arif, bijaksana, ksatria, tawadhu, sederhana, visioner, solutif, komunikatif dan inspiratif. (Salahudin, 2011:25)

Di Amerika serikat, konsep pendidikan karakter memiliki enam nilai etik utama, yang diterapkan pada sistem pendidikan karakter dan dikenal dengan sebutan Six Pillars of Characters (Josephson, 200:1)

Trustworthiness (dapat dipercaya; 2) Respect (memperlakukan orang lain dengan hormat); 3) Responsibility (tanggung jawab; 4) Justice and Fairness (Adil dan seimbang); 5) Caring (perhatian dan kasih sayang); dan 6) Civic virtue and Citizenship (Sikap warga negara yang baik). (Salahudin Wahid, 2011:25)

Pendidikan karakter menurut Prof Mochtar Buchori, seharusnya mengarahkan peserta didik ke pengenalan dan penghayatan nilai secara kognitif, penghayatan nilai secara efektif dan akhirnya sampai pada pengamalan secara kongkrit. Agar sampai kepada pengamalan dibutuhan proses batin sehingga munculkan keinginan yang kuat sehngga bisa mengamalkan nilai tersebut. Istilah seperti itu dinamakan conatio dan langkah untuk membimbing anak dengan mengutkan tekad dinamakan conatif. Sedangkan meneurut $\mathrm{Ki}$ Hajar Dewantara proses penterjemahan itu disebut dengan istilah cipta, rasa dan karsa.

Dr. Doni Koesuema, menulis buku "pendidikan karakter", menurutnya pendidikan karakter jika ingin efektif dan utuh harus memenuhi beberapa keteria diantanya:
Pertama, desain pendidikan karakter menggunakan kelas. Bentuk ini berbasis pada relasi guru sebagai pendidik dan siswa sebagai pelajar. Guru dan siswa bukan menolong tetapi dialog dengan banyak arah. Kedua, pendidikan karakter berlandaskan kultur sekolah. Bentuk ini mencoba membangun kultur sekolah yang mampu membentuk karakter anak didik dengan bantuan pranata sosial di sekolah agar nilai terinternalisasi pada diri siswa. Pesan moral tersebut diperkuat dengan penciptaan kultur kejujuran melauiperaturan sekolah yang ketatKetiga, bentuk pendidikan berbasis komunitas. Dalam mendidik komunitas tidak berdiri sendiri sendirian. Melibatkan masyarakat dular lembaga contohnya keluarga, masyarakat umum, dan negara juga memiliki tanggung jawab moral untuk mengintegrasikanpembentukan karakter. Apabila lembaga lemah dalam penegakan hukum, apabila mereka bersalah tidak pernah mendapatkan sanksi yang sebanding,negara telah mendidik masyarakatnyauntuk menjadi manusia yang tidak menghargai masyarakat.Ketika pejabat mempunyai dana dalam jumlah teramat besar, akan tetapi diselewegkan alias korupsi. (Salahudin, 2011:25)

Kita perlu meninjau konsep pendidikan dalam buku Adab Aim wal Muta'alim karya Hadratus Syaikh Hasyim Asy'ari. Menurut beliau, tujuan pendidikan Islam tidak hanya berhenti pada tingkat kognitif saja tapi lebih dari itu, adalah pada pengamalan terhadap ilmu 
yang telah diperoleh seorang santri yang disebut ilmu bermanfaat (ilmunafi). Keberhasilan seorang santri pada sejauh mana santri mengamaliyahkan ilmu agama yang telah didapat pada kehidupan sebenarnya. Seandainya berbicara perihal sifat keikhlasan dan pengorbanan dalam berjuang. Kyai Hasyim Asy'ari tidak berarti apa-apa kalau kata dan konsep tersebut tidak kita terapkan dalam diri dan tingkah laku kita. Dengan ini sebenarnya Kyai Hasyim Asy'ari dengan ukuran 'ilmu nafinya sejajar dengan pembentukan karakter yang tengah ramai diperbincangkan sebagai solusi mengembangkan akhlak yang sudah merosot secara meluas di beberapa bidang seperti bidang pendidikan dan sosial (Hasyim, 2010:43)

Isi pembelajaran isi kitab Talim muta'alim menciptakan manusia yang tak hanya mempunyai integritas keilmuan yang memadahi tetapi juga integritas moral yang akan menjadi modal utama ketika seorang santri kembali ke tengah masyarakat jadi bagi Kiai Hasyim kemuliaan ilmu dan ulama' terletak pada ulama yang berjuang di masyarakat yang sepenuhnya mencari ridho Allah, bukan demi harta, pangkat maupun nama besar. Ini oleh Kiai Hasyim disebut dalam karyanya sebagai khoir al-bariyah yaitu pencapaiaan pada derajat insan yang mulia.

Kemudiaan pertanyaannya adalah bagaimana seorang Kiai Hasyim dengan konsep pendidikannya mampu mencetak ulama-ulama besar pada masanya? Ini mungkin karena seorang guru (mu'allim) atau Kiai tidak hanya memberikan pegajaran yang sfatnya penuturan di dalam kelas tapi juga teladan yang mampu membentuk karakter seseorang anak didik (santri).

Oleh karena itu tidak berlebihan kalau pesantren pada masa itu dikatakan sebagai laboratorium karakter yang sangat sukses. Namun pada saat ini tentu tidak mudah untuk mengimplementasikan apa yang telah dikonseptualisasikan Kiai Hasyim dan yang juga telah dipraktekannya, kalau kita melihat tantangan yang semakin berat.

Amanah Hadratus Syekh Hasyim Asy'ari berupa, cita-cita, tujuan, prinsip, dan ajaran yang harus dilestarikan melalui pendidikan dan perjuanagan sosial. Sudah menjadi teradisi, para pengasuh dan santri alumni Tebuireng selalu peduli dengan nasib bangsa sejak awal kelihainya hingga kini.

Kemajuan dibidang fisik tidak banyak artinya bila tidak menghasilkan manusia yang berperilaku baik dan berilmu, kemajuan fisik mash belum sepeti yang diharapkan kalau kita membandingkan pesantren Tebuireng 60-70 tahun yang lalu. Keluarga besar Hasyim Asy'ari sudah menyatu dan diharapkan dapat turut membantu memajukan Pesantren Tebuireng. Untuk membahas hal-hal penting di dalam keluarga, didirikan Majelis keluarga beranggotakan perwakilan dari tiap putra /Hasyim Asy'ari Arah pendidikan di Tebuireng sudah benar Tebuireng ingin memajukan ilmu agama dan non agama sampai 
tingkat Universitas. Untuk pendidikan dalam arti pembentukan akhlak / karakter, masih banyak yang harus dilakukan Pesantren Tebuireng masih mempertahankan apa yang sudah ada, yang sudah lumayan. Tetapi pembentukan karakter sesuai dengan tantangan zaman, sedang mencari bentuk yang tepat (Salahudin Wahid, 2011:25)

Upaya pembentukan karakter di pesantren Tebuireng sangat terncana dalam rangka menghadapi tantangan masa era yang akan datang, K.H. Salahudin Wahid mencoba mengambil inti sari dari nilai-nilai yang telah wariskan oleh K.H. Hasyim Asy'ari yang tercantum dalam kitab-kitab beliau. Pesantren Tebuireng menyaring 5 nilai-nilai yang ditanamkan kepada para santri, Kelima nilai tersebut adalah: ikhlas, jujur, kerja keras, tanggung jawab dan tasamuh. Tasamuh ialah peduli, toleran, anti kekerasan, sikap lapang hati, menghargai perbedaan dan menghargai hak orang lain. (Salahudin Wahid, 2011:28)

K.H. Salahudin Wahid akan terus berusaha mencari cara yang tepat untuk bisa berhasil menginternalisasikan 5 (lima) nilai yang telah diambil dari warisan K.H. Hasyim Asy'ari. Ditargetkan dalam 1-2 tahun kedepan kami sudah menemukan metode yang tepat untuk bisa menerapkan pendidikan akhlaq. Tentu saja harus dilakukan proses evaluasi dan perbaikan terhadap metode itu. Yang bersifat nahi mungkar sudah cukup berhasil dilakukan, tapi yang bersifat amal ma'ruf masih belum mencapai target yang diharapkan
Kerjasama dengan sejumlah pihak yang punya pengalaman dan keberhasilan dalm masalah pembentukan karakter dengah dilakukan. Diharapkan dalam pendidikan karakter dalam lima tahun kedepn upaya peningkatan karakter akan mengalami kemajuan berarti. Disadari bahwa tanpa keberhasilan pembentukan karakter itu, Pesantren Tebuireng tidak bisa dianggap berhasil.

Tentu masih banyak nilai-nilai yang positif yang perlu ditanamkan kedalam diri santri, misal sikap adil, rasa malu, percaya diri,komiten disiplin, keberanian, harga diri, motivasi, berfikir positif, berbaik sangka, kesederhanaan, rendah hati, hemat, teliti. Nilainilai tersebut dapat dimasukan atau digabungkan kedalam lima nilai diatas.

Keteladanan adalah kata kunci di dalam pembentukan karakter. Jadi lima perinsip warisan K.H. Hasyim Asy'ari itu harus dijalankan oleh Pengahsuh Pesantren Guru, Pembina, dan semua komponen yang di Pesantren Tebuireng. Pendidikan pesantren akan bisa berefek jika pendidikan kakter bisa dilaksanakan secara bersamaan, senirgis dan konsekwen. Tanpanya pendidikan kita hanya akan bersifat parsial, inkonsisten dan tidak efektif. (Salahudin Wahid, 2011:29)

Di tengah arus modern era disrupsi 0.4, nampaknya gagasan KH. Salahdin Wahidtentangpendidikan Islam berbasis nilai akhlak khsusnya di stakholdes lembaga pendidikan Islam yang sudah dilakukan di 
lembaga pesantren Tebuireng dan lembaga formalnya. Hasilnya menunjukan keberhasilan dan suksesi yang telah dilakukan oleh K.H. Salahudin Wahid maka pemikiran tentang nilai pendidikan islam layak untuk ditawarkan menjadi percontohan kependidikan yang cakupanya yang luas ke pendidikan yang berbasisis pesanteren dan,ajaranya ditekankan pada niai-nilai keislaman dan harusmengutamakan pengamalan akhlak dan perubahan perilaku yang mulia.

\section{E. Kesimpulan}

Merujuk dari pembahasan diatas bahwasanya konsep nilai pendidikan Islam yang sudah diterapkan dan dibuktikan oleh KH. Salahudin Wahid di Pesantren Tebuireng sesungguhnya nilai pendikan islam yang di internalisasikan kepada semua stakeholders Pesantren Tebuireng, nilai tersebut pada dasarnya bersumber dari Al-qur'an dan sunah rasul kemudian dikembangkan oleh ulama alim terdahulu seperti K.H. Hasyim Asy'ari dengan menulis kitab Adabul Alim Walmuta'alim dan kitab-kitab lainya, yang isinya menulis tetentang ajaran nilai pendidikan islam,tujuannya nilai tersebut untuk merubah mental stakhalders atau murid dan juga supaya lembaga tersebut bisa berkembang dan maju tentunya kunci utama peningkatan perilaku stakeholders dan murid yang baik mau diajak maju tentunya harus ditanamkan nlai-nilai kebaikan pendidikan islam seperti nilai: kejujuran, kerja keras, ikhlas, tanggung jawab, toleransi, keterbukaan dan kemandirian. Realitas dilapangan stakeholders dan seorang murid harus ditanamkan nilai kemandirian supaya dapat mengembangkan pontesinya dan mengamalkan nilai pendidikan islam harus seimbang dan diberi ruang untuk berusaha berfikir keras, sehingga mereka mampu mengamalkan nilai tersebut dilingkungannya

Dalam implementasipemikirannya K.H. Salahudin Wahid nilai pendidikan islam yang sudah diimplementasikan di Pesantren Tebuireng kepada seluruh stakeholders dan murid melalui internalisai nilai penidikan islam diantaranya:kejujuran, kerja keras, keikhlasan, tanggung jawab, toleransi keterbukaan dan kemandirian selain itu juga dalam memajukan Pesantren Tebuireng K.H. Salahudin Wahid lebih memilih pendekatan komunikasi, dialogh dan mengadakan rapat, kemudian dilapangan beliau berusaha menyatukan keluarga beliau mendatangkan narasumber yang kompeten pada bidangnya tujuaanya dalam rangka merubah mental stakeholders dan murid melalui penanman nilai-nilai pendidikan islam dengan seperti itu kata beliau, akan mudah menggerakan dan memajukan Pesantren Tebuireng karena kuncinya adalah SDM pesantren Tebuireng Hasil evalusi pemikirian K.H. Salahudin Wahid tentang keberhasilan nilai Jurnal Al-Fikri Volume 3 Nomor 1 - Februari 2020 


$$
\text { pendidikan islam yang perestasinya dalam rangka memajukan }
$$

diinternalisasikan pada stakehoders dan murid Pesantren Tebuireng

Pesantren Tebuireng hasilnya sangat

Lebih jauh lagi pemikiran K.H. memuaskan, terbukti banyak perubahan- Salahudin Wahid nilai pendidikan islam yang perubahan yang signifikan dari mulai sikap sudah terbukti di Pesantren Tebuireng bisa dan perilaku para guru, karyawan dan santri diterapkan dilembaga yang lain atau menjadi semua mengalami perilaku yang baik dan alternatf dan solusi bagi perbaikan dalam mendapatkan prestasi yang menggembirakan. akhlaq, sehingga dengan perbaikan tersebut, perestasi tersebut harus dipertahankan, dijaga lembaganya bisa berubah dan meningkat, dan dilestarikan serta dievalusi terus-menerus manfaat lainnya nilai pendidikan islam supaya lebih berkembang dan meningkat tersebut bisa sebagai benteng moral dalam menghadapi tantangan di era disrupsi saat ini. 


\section{Referensi}

SalahudinWahid,Berguru pada realitas $\mathrm{UIN}$ Maliki Press : Malang.,2011

Salahudin Wahid, Tranformasi Pesantren Tebuireng: UIN Maliki Press: Malang, 2011

Pendidikan Islam, Demokratisasi dan Masyarakat Madani. Yogyakarta : Pustaka Pelajar, Tilaar,H.A.R. Paradigma Baru Pendidikan Nasional. Jakarta: Rineka Cipta, 2000.

Basri, Hasan. Filsafat Pendidikan Islam. Bandung: Pustaka Setia, 2009

Yamin, Moh. Menggugat Pendidikan Indonesia. Yogyakarta: Ar-Ruzz Media, 2009

Imron Arifin Kepemimpinan Kyai Pesantren:

Surabaya Kalimatu Sahadah, 2006,

Taufqurahman Kyai Manejer,Maliki Press: Malang, 2011

SalahudinWahid Mendengar Suara rakyat catatan pendek:Maliki Press, Malang, 20011

SalahudinWahidMemadukanKeindonesiaan dan Keagamaan:Maliki Press, Malang, 2011Salahudin Wahid Ikut Membangun demokrasi: Maliki Press, Malang, 2011

Rahardjo. Pemikiran KebijakanPendidikan Kontemporer. Malang:uinpress, 2010.

Muhaimin.

PemikirandanAktualisasiPengembangan
Pendidikan Islam. Jakarta: Rajawali Pers. 2012

Darajat, Zakiah. Ilmu Pendidikan Islam. Bandung: Bumi Aksara, 2008.

Marimba, Ahmad D. Pengantar Filsafat Pendidikan Islam. Bandung: al-Maarif, 1962.

Mujamil. Qomar, EpistemologiPendidikan Islam: Dari MetodeRasionalHinggaMetodeKritik. Jakarta: Erlangga. 2006.

.Sanusi.K. H. A. Wahid Hasyim Mengapa Memilih NU? Konsepsi Tentang Agama, Pendidikan dan Politik. Jakarta: Inti Sarana Aksara, 1985.

Dhofier, Zamakhsyari. Tradisi Pesantren Studi Pandangan Hidup Kyai dan Visinya Mengenai Pendidikan Agama Islam (JPAI)FTK UIN Sunan Ampel Surabaya, Vol 1, No 2 (2013).

Moh. Ismail Jurnal Pendidikan Agama Islam Volume 4 Nomor 2 Nopember 2016 ISSN (p)2089-1946\& ISSN(e) 25274511Hal. 336-336

Ismail.Pendidikan Islamdan Masyarakat Madani. Yogyakarta: Pustaka pelajar, 2000

Hasyim Asy'ari.Adabul Alilm walal

Mutaalim:Trus Islamiy Jombang, 2003

Abuddinata, Tokoh Pembaharu Pendidikan Islam di Indonesia: Jakarta, Rajagrafindo, 2011

Jurnal Al-Fikri Volume 3 Nomor 1 - Februari 2020 
Salahudin

TradisidanKeilmuanPesantren

Transformatif menjawab zaman: Majalah

Tebuireng, 2019

Tilaar,H.A.R. Paradigma Baru Pendidikan

Nasional. Jakarta: Rineka

Cipta,2000Achmad. K.H. Abdul Wahid

Hasyim Pembaharuan Pendidikan

Jakarta: Panitya Buku

Mas'ud, Abdurrahman. Menggagas Format

Pendidikan Nondikotomik; Humanisme Religius Sebagai Paradigma Pendidikan Islam. Yogyakarta : Gama Media, 2002

Salahudin Wahid Jiwa kebangsaan : Majalah Tebuireng, 2019
Salahudin Wahid : Kondisi Minat Baca Masyarakat indonesia, Majalah Tebuireng, 2019

Sirozi, M. Politik Pendidikan: Dinamika Hubungan antara Kepentingan Kekuasaan dan Praktik Penyelenggaraan Pendidikan. Jakarta: Raja Grafindo Persada, 2005.SM,

Salahudin Wahid : Pendidikan Agama dan Budi Pekerti , Majalah Tebuireng, 2019

Salahudin Wahid : 120 Tahun Pesantren Tebuireng, Majalah Tebuireng, 2019 Salahudin Wahid : Menggali Kaloborasi Nilai Agama dan Kebudayaan, Majalah 